\title{
BRAIN RATE PARAMETER IN CHILDREN WITH GENERAL ANXIETY DISORDER
}

\author{
Aneta Demerdzieva ${ }^{1}$ and Nada Pop-Jordanova ${ }^{2}$ \\ ${ }^{1}$ Acibadem Sistina Hospital, Sistina Hospita, Skopje, Republic of Macedonia \\ ${ }^{2}$ Macedonian Academy of Sciences and Arts, Skopje, Republic of Macedonia
}

Corresponding author: Nada Pop-Jordanova, Bul Krste Misirkov br.2, P.O.Box 428, 1000 Skopje, Republic of Macedonia, e-mail: popjordanova.nadica@gmail.com

\section{ABSTRACT}

Introduction: Brain rate is parameter correlated to brain electric and metabolic activity.

Aim: The aim of this study was to analyze the results obtained for brain rate parameter as an indicator for general mental arousal in anxious patients and to compare them with results of healthy young people matched in age and gender, as well as with anorectic and hyperactive children.

Material and Methods: The diagnosis for all examinees was made according two statistic manuals (DMSIV-R and ICD-10), medical history, neuropsychological assessment, biochemical analysis and QEEG. In this study we examined the spectra power of the brain waves through quantified EEG (QEEG). The obtained results were exported to brain rate software and then calculated for each region separately. The QEEG spectra power data and the brain rate data were analyzed using Statistica software.

Results: According to sagittal and lateral topography maximal values of brain rate parameter were obtained in group of healthy individuals and in group of anorectic patients. The lowest results were obtained in group of hyperactive children for all three regions.

Conclusions: The general conclusion will be that pathological conditions in childhood, analyzed in this research, can be defined as conditions of hypoarausal and this can be specific sign of brain dysfunction.

Keywords: QEEG, brain rate

\section{INTRODUCTION}

Mental arousal (as a general activation of the mind) is characterizing the level of consciousness, irrespective of its content [Kahneman, 1973]. In 2005 we introduced a relevant parameter - brain rate (expressing the mean frequency of brain rhythms i.e. EEG-spectrum weighted frequency) for calculation of mental arousal [2].

Brain rate can be considered as an integral brain state attribute correlated to brain electric, men- tal and metabolic activity. In particular, it can serve as a preliminary diagnostic indicator of general mental activation in addition to heart rate, blood pressure or temperature, as standard indicators of general bodily activation.

In our research it was shown that as a measure of arousal, brain rate can be applied to discriminate between the groups of under-arousal and over-arousal disorders, as well as the subgroups within "mixed" 
disorders, in particular the attention deficit hyperactivity disorder. Also, by comparing eyes closed and eyes open brain rate values, the diagnosis of inner arousal can be simply achieved.

In addition, brain rate values can be correlated to the sleep profile, helping to assess the quality of sleep. In biofeedback treatment, brain rate can be efficiently used as a multiband biofeedback parameter, complementary to few-band parameters and skin conduction. Hereby, it is especially suitable to reveal the patterns of sensitivity/rigidity of EEG spectrum, including frequency bands related to permeability of corresponding neuronal circuits, based on which the individually adapted biofeedback protocols can be elaborated.

Brain rate can be calculated by the following formula:

$$
f_{\mathrm{b}}=\sum_{i} f_{i} P_{i}=\sum_{i} f_{i} \frac{V_{i}}{V} \quad V=\sum_{i} V_{i}
$$

(Where the index $i$ denotes the frequency band (for delta $i=1$, for theta $i=2$, etc.) and Vi is the corresponding mean amplitude of the electric potential or power).

Interpretations of results of brain rate need experience and good knowledge of specific QEEG pattern according to age and developmental stage, especially during childhood. As very illustrative we will cite an example from ref. [2] that $\mathrm{fb}=4.59$ for an adult would correspond to a very drowsy state (or mental retardation) and a relaxed state for a child, while $\mathrm{fb}=9.58$ would correspond to a relaxed state for an adult, and a very attentive (or anxious) state for a child.

Starting from the assumption that different brain rate values are somehow coupled with metabolic activity in different disorders, it is very interesting to compare it with the same parameter of normal (healthy) subjects. The aim of this study was to analyze results obtained for brain rate parameter, as an indicator for general mental arousal in young anxious patients and to compare them with the results of healthy people on the same age and gender. Additionally, some comparison between results obtained for ADHD children and anorectic patients will be discussed.

Generalized anxiety disorder in childhood is characterized by recurrence of excessive, disproportionate and intrusive concerns or worries (related to child's performance at school, sport activities, physical health, family financial situation, catastrophes, possible disasters) in a period of one month at the least. Abnormalities in brain functioning in anxious children and young patients are quite often approved by neuroimaging techniques.

\section{METHODS AND PARTICIPANTS}

The examined subjects were divided into two groups - patients with General Anxiety Disorder, and control group of healthy children. The first group comprised 40 anxious young people; mean age 12 $( \pm 3.5)$ years. Girls were $17(42.5 \%)$ and $23(57.5 \%)$ were boys. The control group comprised 25 healthy children, selected by chance and matched by age and gender with the group with GAD.

All subjects were patients of the Department for Psychophysiology at the University Pediatric Clinic in Skopje. The diagnosis was made according to two statistic manuals: DMS-IV-R (American Psychiatric Association: Diagnostic and statistical manual of mental disorders DSM-IV, 4th Ed, 1994) and ICD-10 (World Health Organization: The ICD10 classification of mental and behavioural disorders. Diagnostic criteria for research, 1993). Medical history, neuropsychological assessment and QEEG has been realized in all examinees.

Inclusion criteria were: age between 7 and 18 years; absence of actual neurological impairment and absence of the use of psychoactive or psychotropic substances (screened by a previous anamnesis and clinical examination). All subjects had normal or corrected to normal vision. Informed consent for QEEG recording has been appropriately obtained from all participants/caregivers. Anxious group was assessed with psychological testing comprising Generalised Anxiety Scale-GASC and Eysenck Personnality Questionnaire-EPQ in a single session; Subjects were free of any medication 48 - hours before testing and were asked to have good sleep a night before testing. They all had to have a meal before testing to avoid effects of hypoglycemia on the brain function. They were seated in a comfortable chair with a backrest and were instructed not to move their eyes during the recording.

EEG was recorded with Quantitative EEG equipment (Mitsar, Ltd.) amplifier of 19 electrodes, referenced to linked ears (on the International 10-20 system) with $250 \mathrm{~Hz}$ sampling rate in $0.3-70 \mathrm{~Hz}$ frequency range in the following conditions: 1) Eyes opened (EO) - 5 minutes, 2) Eyes closed (EC) 5 minutes, 3) Visual continuous performance task 
(VCPT) - 20 minutes and 4) Auditory continuous performance task (ACPT) - 20 minutes.

The 19 electrode positions were allocated to three sagittal regions:

$\sqrt{ }$ Frontal-Fp1, Fp2, F3, Fz, F4, F7 and F8.

$\checkmark$ Central - T3, T4, C3, Cz and C4.

$\sqrt{ }$ Posterior - T5, T6, P3, Pz, P4, O1 and O2.

The obtained results were analyzed, exported to brain rate software and then calculated for each region separately. The QEEG spectra power data and the brain rate data were analyzed using Statistica software (version 10.0). A series of repeated measures analysis of variance - Factorial ANOVA was performed using the factors: sagittal topography (frontal, central and posterior region), measurement condition (EO, EC, VCPT and ACPT) and group (disorder and controls) for spectra power values. Additionally, post hoc Bonfferoni test was performed to explain significant interactions of obtained data.

\section{RESULTS}

Firstly, we will present results for calculated power spectra for anxious vs healthy children in different positions.

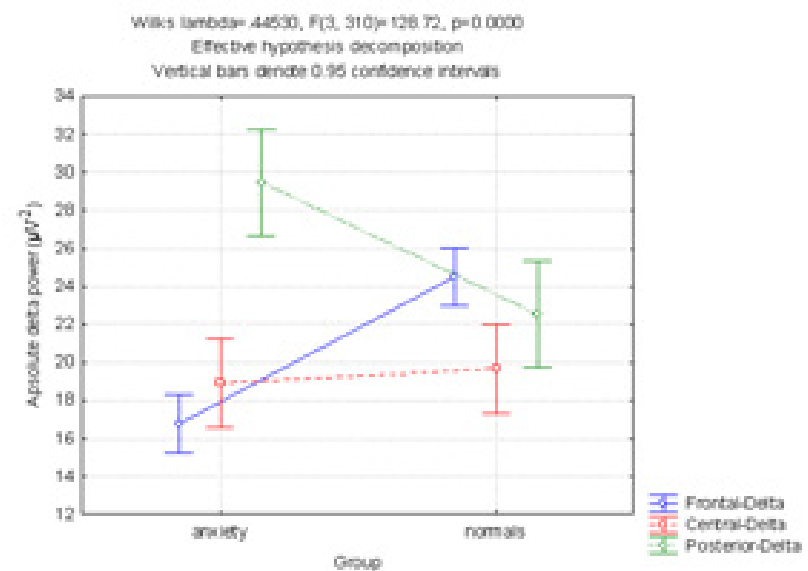

Fig 1. Delta power in sagittal topography

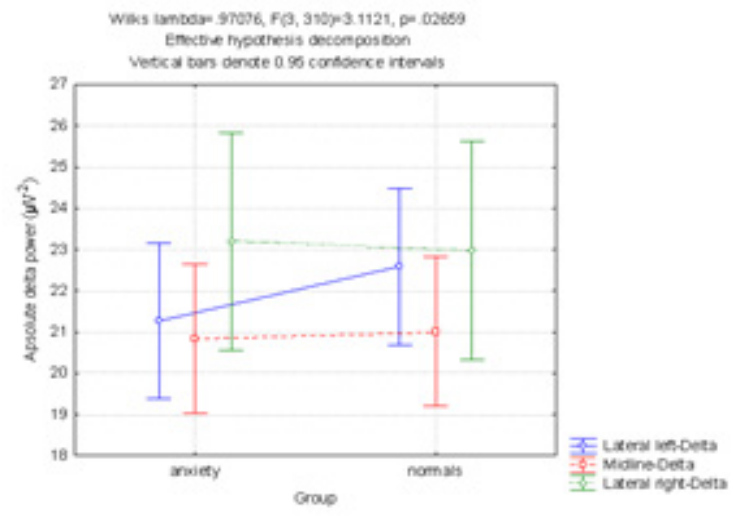

Fig 2. Delta power in lateral topography

As can be seen the main difference is obtained in frontal region, where children with anxiety had significant smaller delta power comparing with healthy control.

Calculated post hoc Bonferoni test for delta power shows statistical significance (Table 1).

Table 1. Summary results for post hoc Bonferoni $p$ values for delta spectral power compared between anxious and control group

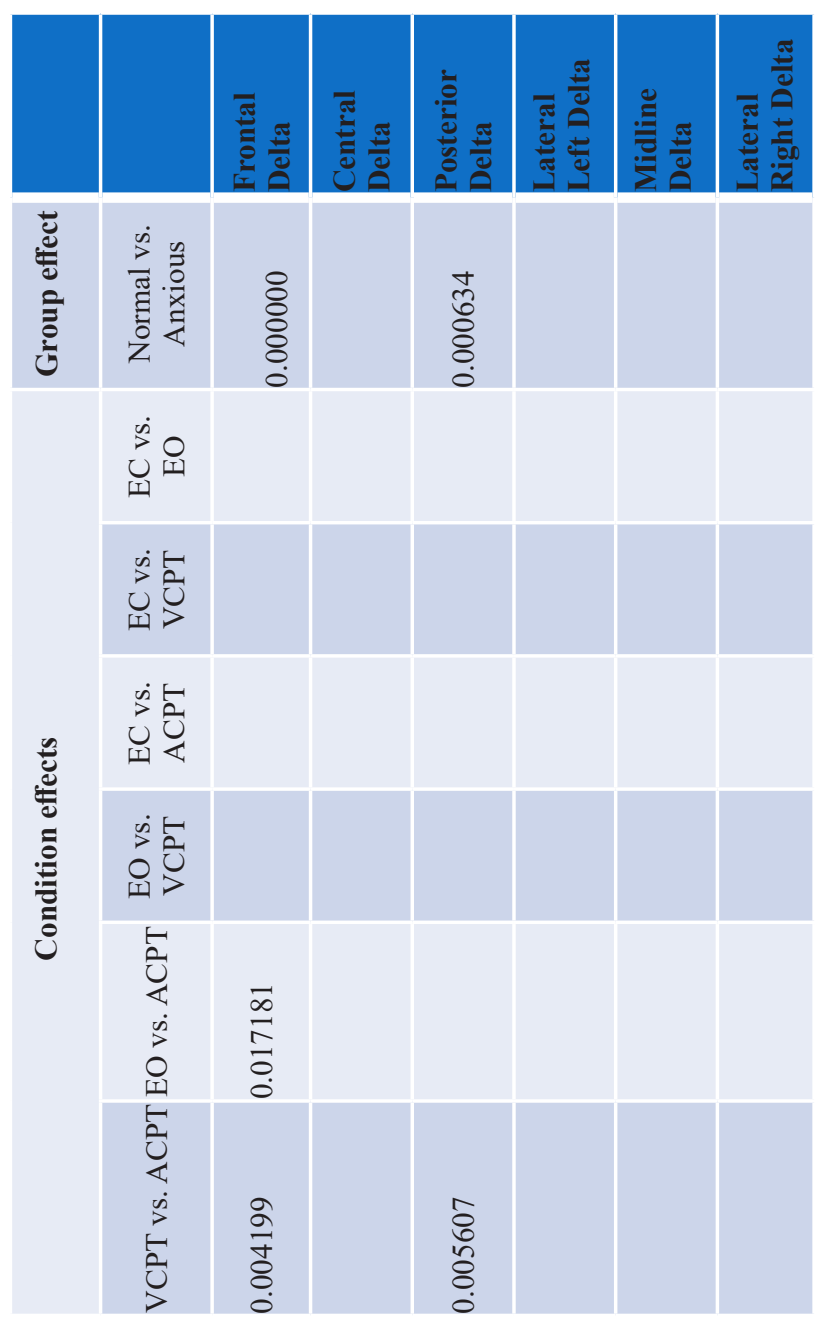


For theta spectral power in both position significant differences between anxious and control group were obtained ( $p<0,001)$, which is confirmed with post hoc Bonferoni test.

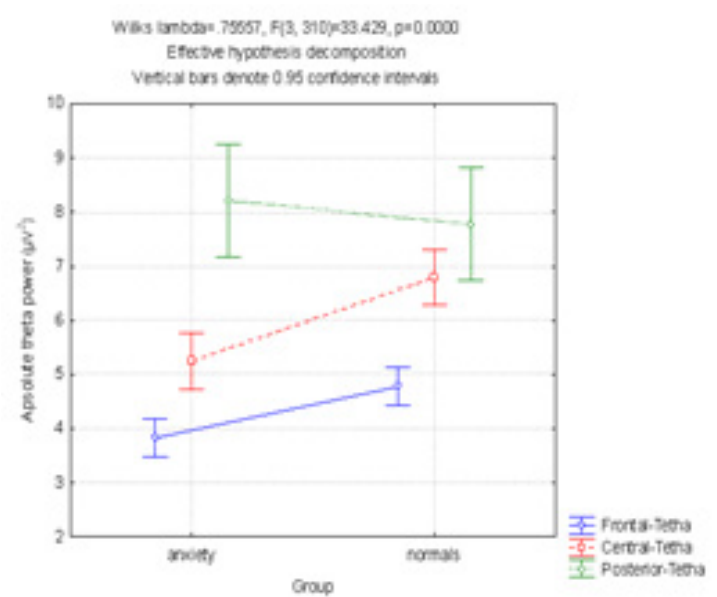

Fig 3. Thetha power for sagittal position

Results are presented in mean values $\pm S D$ $(F=33.43 ; p<0.001)$

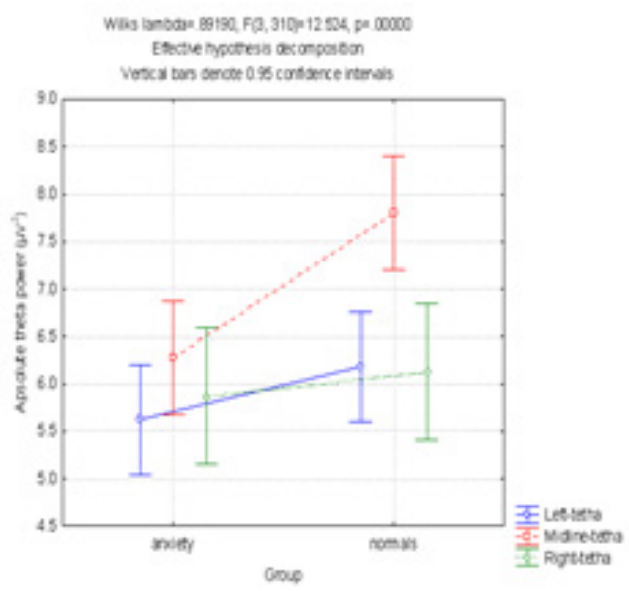

Fig 4. Thetha power in lateral position

Results are presented in mean values $\pm S D$ $(F=12.52 ; p<0.001)$
Table 2. Calculated post hoc Bonferroni test for $p$ values for theta power
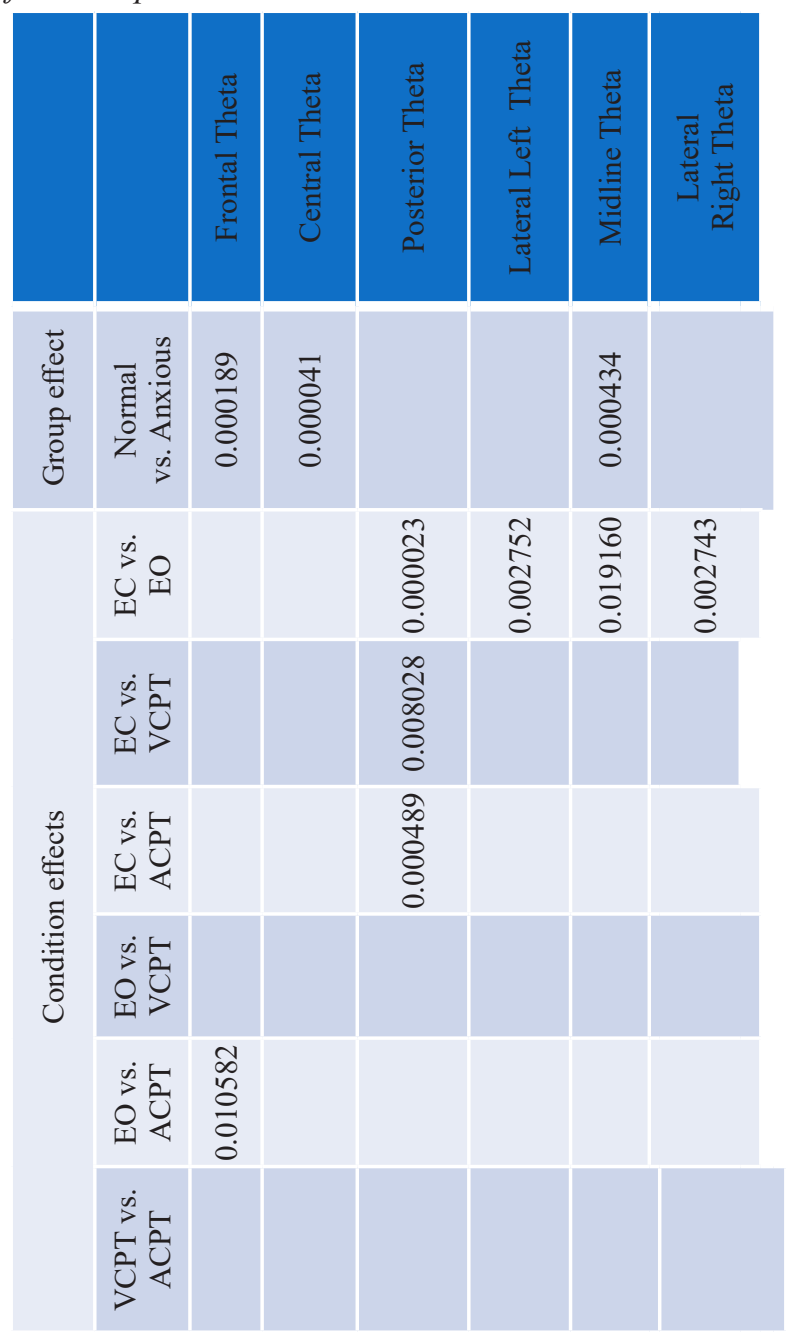

Spectra power for alpha bend in sagittal and lateral position is presented in Fig 5 and Fig 6.

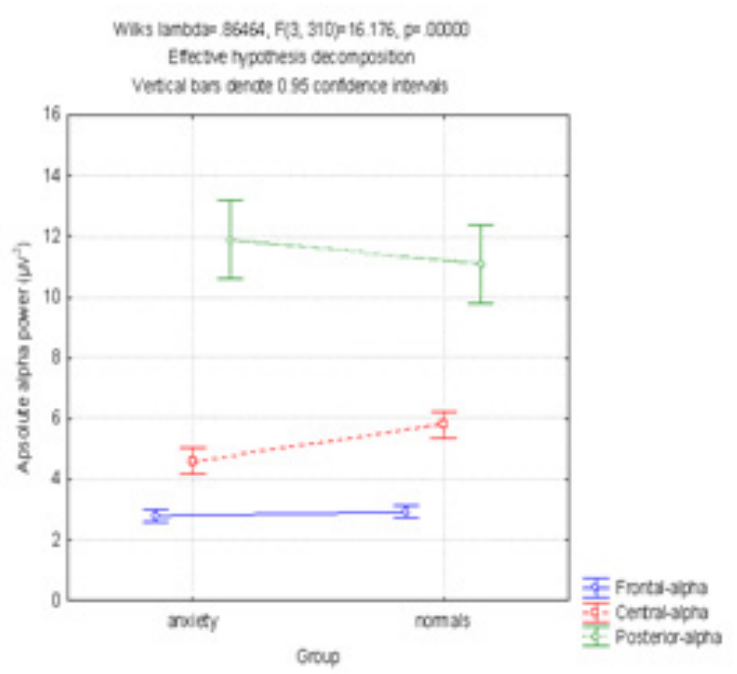

Fig 5. Alpha power according sagittal position $\mathrm{F}=16.18 ; \mathrm{p}<0.001)$ 


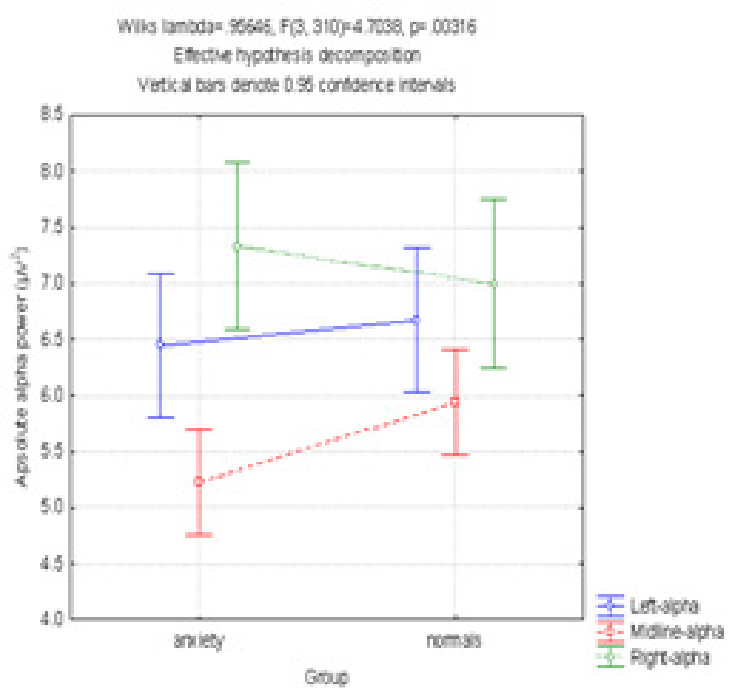

Fig 6. Alpha power according lateral position $(F=4.70 ; p<0.05)$

Statistical significance of differences in both position for alpha spectral power between anxious and healthy children is confirmed with post hoc Bonferroni test (Table 3).

Table 3. Calculated post hoc Bonferroni for alpha power

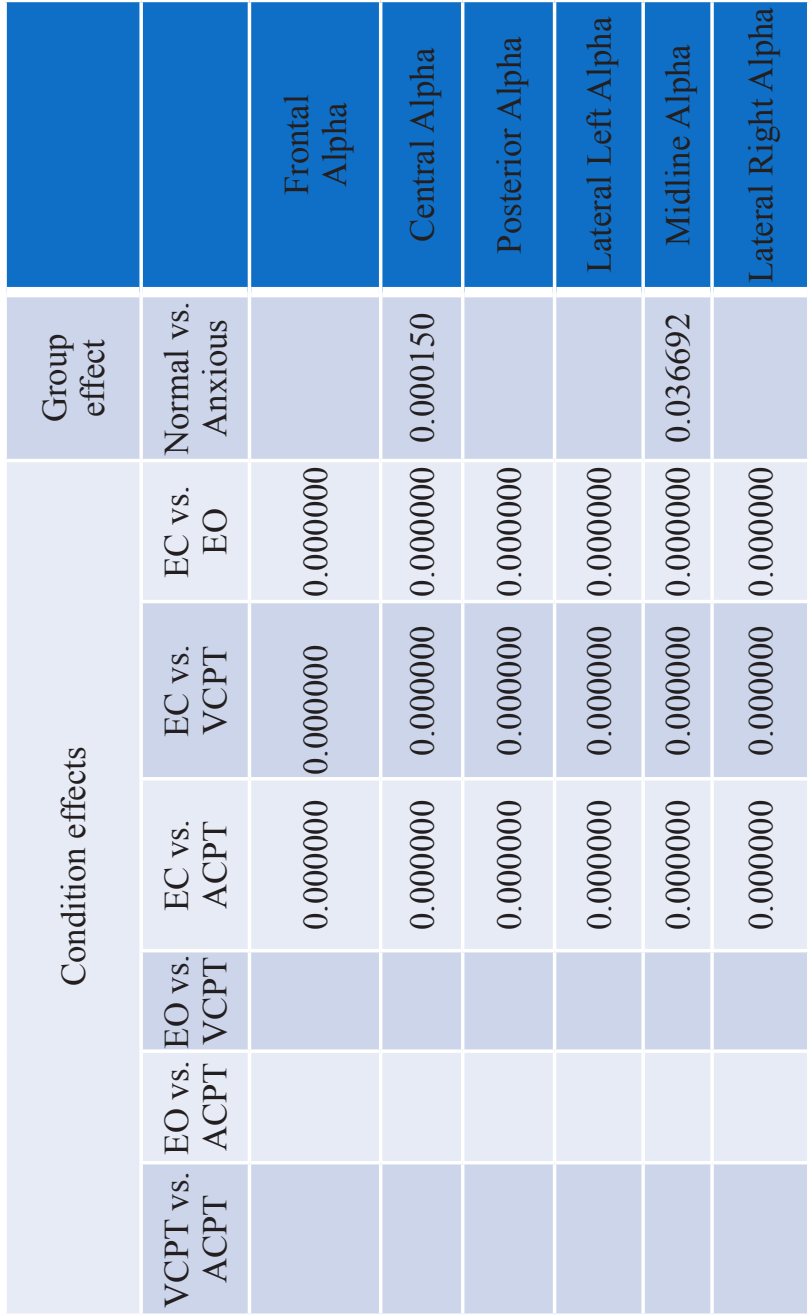

Finally, obtained spectra power for beta band in both positions is presented in Fig. 7 and 8.

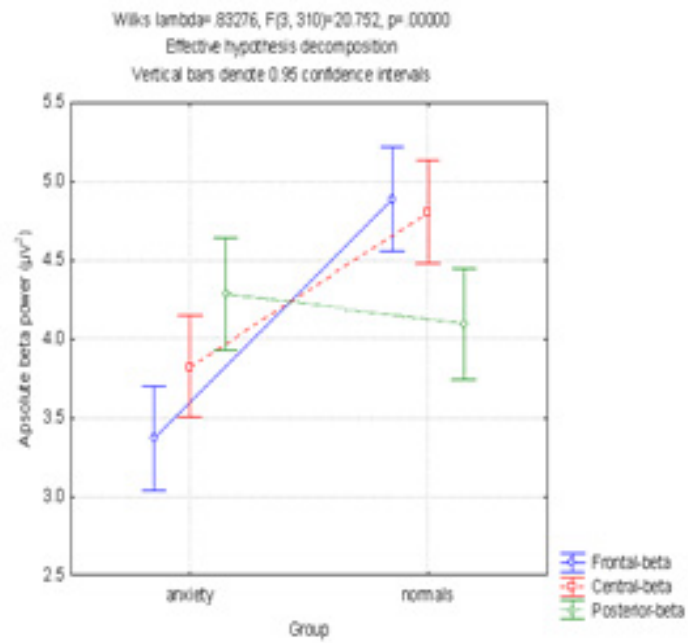

Fig 7. Spectral power for beta in sagittal position $(F=20.75 ; p<0.001)$

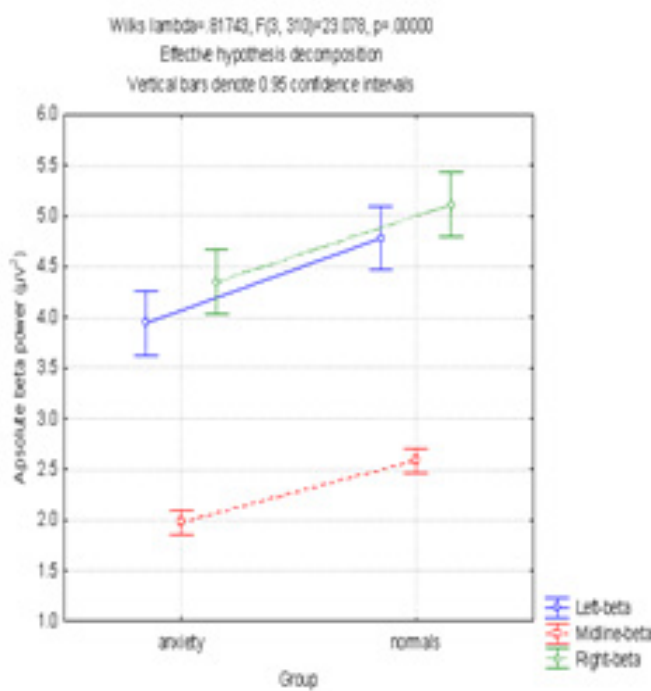

Fig 8. Spectral power for beta in lateral position $(F=23.08 ; p<0.001)$

Statistical significance of differences is confirmed with post hoc Bonferroni test (Table 4). 
Table 4. Post hoc Bonferroni test for $p$ values for beta ly significant correlation with factor group $\mathrm{F}$ waves

\begin{tabular}{|c|c|c|c|c|c|c|c|}
\hline & & 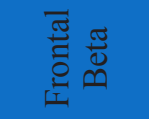 & 苞 & $\begin{array}{l}.0 \\
\frac{0}{0} \\
\frac{\pi}{0} \\
0 \\
0\end{array}$ & 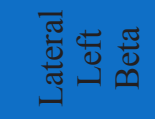 & $\frac{\stackrel{\pi}{\Xi} \frac{\pi}{0}}{\sum^{\infty}}$ & 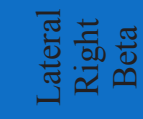 \\
\hline 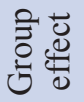 & $\begin{array}{l}\text { Normal } \quad \text { vs. } \\
\text { Anxious }\end{array}$ & 0.000000 & 0.000034 & & 0.000264 & 0.000000 & 0.000866 \\
\hline \multirow{6}{*}{ 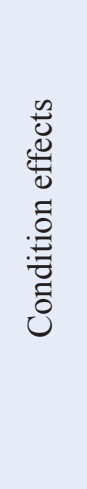 } & EC vs. EO & 0.000064 & & 0.000555 & & & \\
\hline & EC vs. VCPT & 0.000000 & & & 0.001579 & & 0.000015 \\
\hline & EC vs. ACPT & 0.000000 & & 0.001870 & & & 0.002711 \\
\hline & EO vs. VCPT & 0.000017 & & & 0.011706 & & 0.004050 \\
\hline & EO vs. ACPT & 0.000771 & & & & & \\
\hline & VCPT vs. ACPT & & & & & & \\
\hline
\end{tabular}

As it was mentioned before, we calculated the brain rate parameter for an anxious group in both positions (sagittal and lateral) for measuring general mental arousal.

Brain rate results for anxious patients are presented in Fig. 9 and 10.

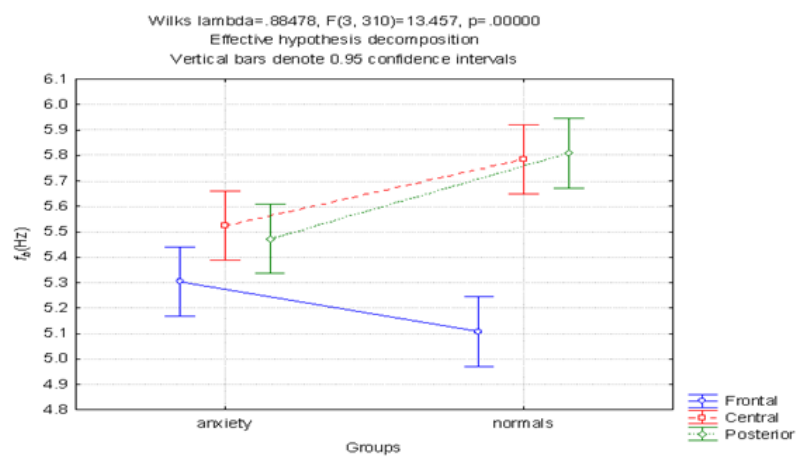

Fig 9. Values of brain rate $\mathrm{fb}$ parameter according to sagittal topography in a group of anxious patients and control group of healthy children (the results are presented as Mean values $\pm S D F=13.46 ; p<0.001$ )

According to sagittal topography $\mathrm{fb}$ parameter in the anxious group has higher results only in the frontal region. In a group of healthy controls the results show statistically significant higher values for central and posterior regions.

The values of brain rate fb parameter according to lateral topography have statistical- region. However, the healthy group showed a higher brain rate (higher arousal).

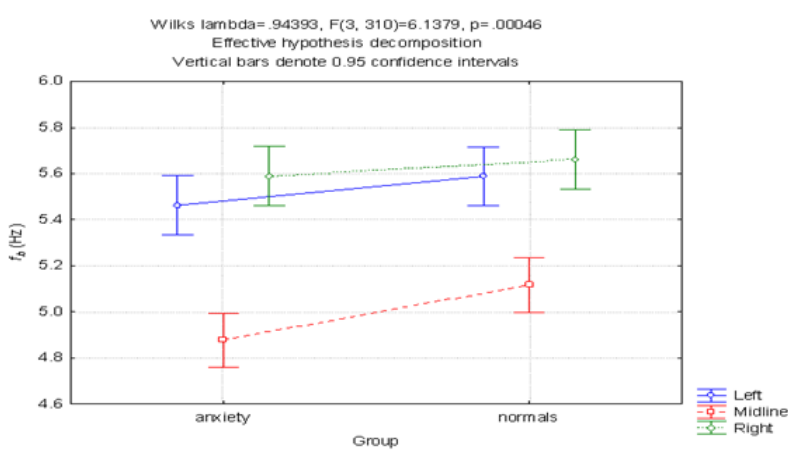

Fig 10. Values of brain rate fb parameter according to lateral topography in a group of anxious patients and control group of healthy children (the results are presented as Mean values $\pm S D F=6.14 ; p<0.0046$ )

In Table 5 post-hoc Bonferroni P-values for brain rate difference between groups, regions and conditions (group of anxious patients and control group of healthy children) is presented. 
Table 5. Summary of significant post-hoc Bonferroni $P$-values for brain rate difference between groups, regions and conditions (group of anxious patients and control group of healthy children)

\begin{tabular}{|c|c|c|c|c|c|c|c|}
\hline & & $\begin{array}{l}\frac{\pi}{0} \\
\frac{\pi}{0} \\
\frac{1}{1}\end{array}$ & & 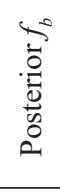 & 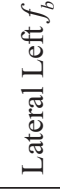 & 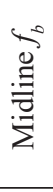 & 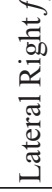 \\
\hline 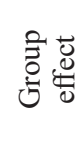 & 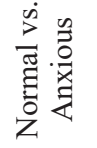 & $\begin{array}{l}n \\
0 \\
0 \\
0 \\
0 \\
0 \\
0\end{array}$ & $\begin{array}{l}n \\
0 \\
0 \\
0 \\
0 \\
0\end{array}$ & $\begin{array}{l}\text { ôे } \\
\vdots \\
\vdots \\
0 \\
0\end{array}$ & & 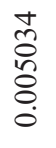 & \\
\hline \multirow{6}{*}{ 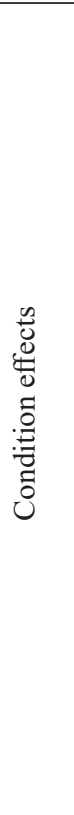 } & $\begin{array}{l}\dot{s} \\
\text { ì } \\
\text { ن्I }\end{array}$ & & & $\begin{array}{l}8 \\
\vdots \\
8 \\
0 \\
0\end{array}$ & 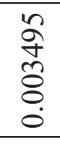 & $\begin{array}{l}8 \\
\$ \\
\$ \\
0 \\
0\end{array}$ & $\begin{array}{l}\text { ô } \\
\text { d. } \\
0 \\
0 \\
0\end{array}$ \\
\hline & 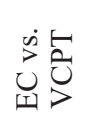 & $\begin{array}{l}\stackrel{1}{0} \\
\text { ڤิ } \\
\stackrel{0}{0}\end{array}$ & \begin{tabular}{l}
$\stackrel{5}{0}$ \\
\multirow{2}{c}{} \\
0 \\
0
\end{tabular} & $\begin{array}{l}8 \\
\vdots \\
\vdots \\
0 \\
0\end{array}$ & & 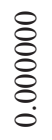 & \\
\hline & 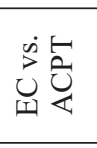 & & 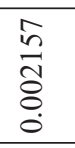 & $\begin{array}{l}8 \\
8 \\
8 \\
0 \\
0\end{array}$ & $\begin{array}{l}0 \\
\stackrel{0}{0} \\
8 \\
0\end{array}$ & $\begin{array}{l}8 \\
8 \\
8 \\
0 \\
0\end{array}$ & $\begin{array}{l}\text { t. } \\
\text { ○े } \\
0 \\
0\end{array}$ \\
\hline & 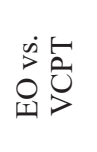 & 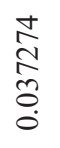 & & & & & \\
\hline & 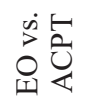 & & & & & & \\
\hline & $\dot{s}$ & & & & & & \\
\hline
\end{tabular}

In a previous research we evaluated groups of anorectic and ADHD children using the same methodology. For comparison with anxious children, we show some statistical calculations of evaluated groups.

According to lateral topography the ANOVA/MANOVA test showed positive correlation of $\mathrm{fb}$ parameter values with factor group with significantly higher values in healthy group. The higher values were obtained for the anorectic group, followed by anxious and then ADHD children. It means that arousal is higher in healthy children which was not expected.
According to lateral topography, as was showed, maximal fb parameter values were obtained in anorectic group and a group of healthy controls $\mathrm{F}=22.51 ; \mathrm{p}=0.0000$.
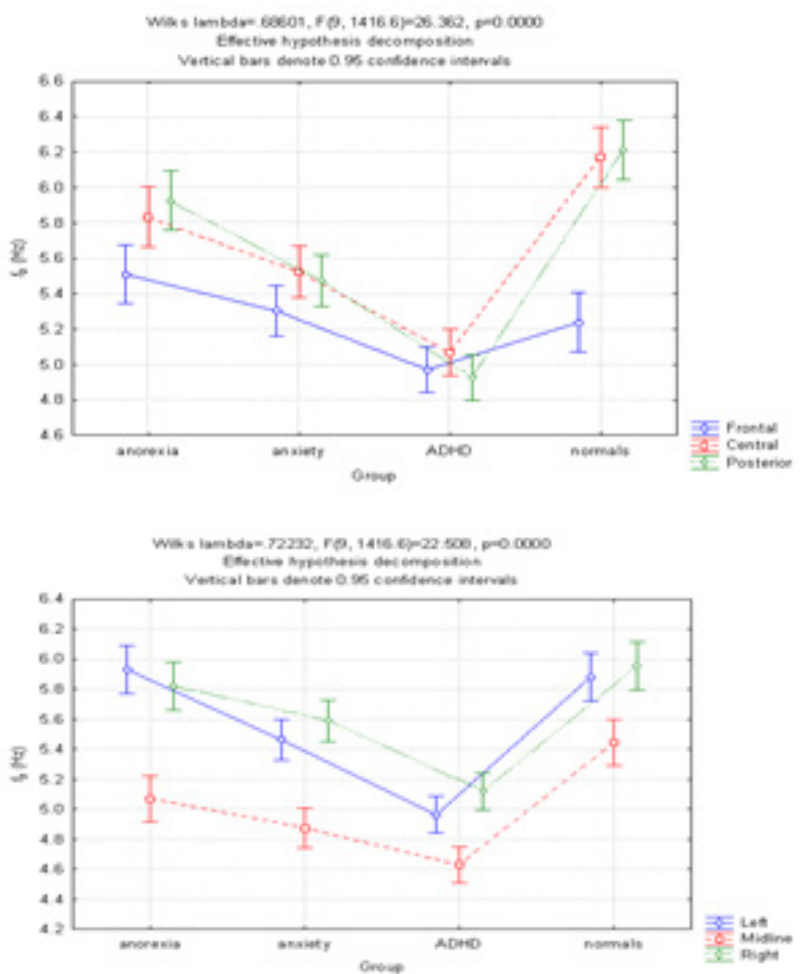

Fig 11. Values of brain rate $f b$ parameter according to sagittal and lateral topography for anorexia, anxiety and ADHD vs. control

(Results are presented as Mean values $\pm S D F=26.36$; $p<0.001$ for sagittal; $F=22.51 ; p<0.001$ for lateral position)

According to sagittal topography maximal $f_{b}$ parameter values were registered in a group of healthy individuals $F=26.36 ; p=0.0000$ in central and posterior region, while in the frontal region maximal values were received in a group of anorectic and anxious patients. The lowest $f_{b}$ parameter values were obtained in a group of hyperactive children for all three regions.

Post hoc Bonferoni-test was used for establishing the differences between groups according to different regions and different conditions. 
Table 6. Summary of significant post-hoc Bonferroni $P$-values for brain rate difference between groups, regions and conditions (group of anxious, anorectic and hyperactive patients and control group of healthy children)

\begin{tabular}{|c|c|c|c|c|c|c|c|}
\hline & & Frontal & Central & Posterior & $\begin{array}{l}\text { Lateral } \\
\text { left }\end{array}$ & Midline & $\begin{array}{l}\text { Lateral } \\
\text { right }\end{array}$ \\
\hline \multirow[b]{5}{*}{ 总 } & $\begin{array}{ll}\text { Normal } & \text { vs. } \\
\text { Anorexia } & \end{array}$ & & 0.035903 & & & 0.004402 & \\
\hline & Normal vs. Axious & & 0.000000 & 0.000000 & 0.000602 & 0.000000 & 0.004262 \\
\hline & $\begin{array}{ll}\text { Normal } & \text { vs. } \\
\text { Hyperactive } & \end{array}$ & & 0.000000 & 0.000000 & 0.000000 & 0.000000 & 0.000000 \\
\hline & $\begin{array}{l}\text { Anorexia vs. } \\
\text { Axious }\end{array}$ & 0.000004 & 0.044061 & 0.000406 & 0.000085 & & \\
\hline & $\begin{array}{l}\text { Anorexia vs. } \\
\text { Hyperactive }\end{array}$ & 0.004850 & 0.000000 & 0.000000 & 0.000000 & 0.000069 & 0.000000 \\
\hline $\begin{array}{l}\text { ڤ్ర } \\
\stackrel{0}{0}\end{array}$ & $\begin{array}{l}\text { Axious vs. } \\
\text { Hyperactive }\end{array}$ & & 0.000044 & 0.000000 & 0.000001 & 0.041795 & 0.000004 \\
\hline \multirow{6}{*}{ 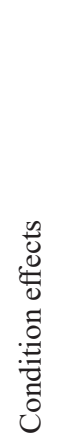 } & EC vs. EO & & 0.006212 & 0.000000 & 0.000000 & 0.000000 & 0.000001 \\
\hline & EC vs. VCPT & & 0.014808 & 0.000000 & 0.000131 & 0.000000 & 0.001054 \\
\hline & EC vs. ACPT & & 0.005622 & 0.000000 & 0.000005 & 0.000000 & 0.000043 \\
\hline & EO vs. VCPT & 0.014948 & & & & & \\
\hline & EO vs. ACPT & & & & & & \\
\hline & VCPT vs. ACPT & & & & & & \\
\hline
\end{tabular}

In this research we started from the hypothesis that anxiety behavior which is basic for all three conditions (anxiety, anorexia and ADHD) can be the result of excess in beta activity. Accordingly, we expected that the results will suggest the condition of hyperarousal in examined patients vs healthy controls. The obtained results were opposite - we received low spectral power for all four bands (delta, theta, alpha and beta), especially for slow bands which could be assumed as specific marker for brain dysfunction. In general, the highest results for brain rate parameter were obtained in a group of healthy children and the lowest results for the group of hyperactive children.
The general conclusion which follows is that pathological conditions in children analyzed in this research, can be defined as conditions of hypoarausal and this can be specific sign for brain dysfunction. However, we must be aware that results obtained with QEEG and brain rate computing are just the framework for further scientific investigation. However, every child is individual story and the treatment must be adjusted according to the individual results and individual based protocols.

Brain rate parameter according to sagittal topography has higher values for anxious group only in the frontal region related to increased mental tension. As it is known, anxiety is defined as a subjective sense of worry, apprehension, fear 
and distress. When severe, it can affect a child's thinking, decision-making ability, and perceptions of the environment, learning and concentration. Basal instability in cortical arousal, as reflected in measures of quantitative electroencephalography (QEEG), is common in most of the anxiety disorders. According to Clark et al. resting electroencephalographic (EEG) measures tend to correlate with symptom sub-patterns and be exacerbated by condition-specific stimulation [5]. There is not much literature for detection of the anxiety states through EEG, and they are considered as complex emotional states $[6,7]$.

Additionally, we analyzed the results between the groups according to sagittal topography and maximal values of brain rate parameter were obtained in a group of healthy individuals in the central and posterior region. Only for anorectic and anxious group of children we received statistically significant higher brain rate values in the frontal region which probably explains increased mental tension, because the frontal region contains most of the dopamine-sensitive neurons in the cerebral cortex. In the frontal region the maximal values were obtained in a group of anorectic patients $-\mathrm{F}(9,1416.6)=26.36 ; \mathrm{p}=0.0000$. According to the lateral topography again, the maximal values were obtained in a group of anorectic and healthy individuals. The lowest results were obtained in a group of hyperactive children for all three regions $-\mathrm{F}(9,1416.6)=22.51 \mathrm{p}$ $=0.0000$. According to the conditions the maximal brain rate parameter values were obtained in eyes closed condition which reflects the state of "inner-arausal" already noted in previous studies of Pop-Jordanov and Pop-Jordanova [19] and Cooper et al. [20].

We started from the assumption that different brain rate values are somehow coupled with metabolic activity in the brain region. Low metabolic activity specific for mental disorders is the explanation for lower values of brain rate in comparison with healthy controls.

According to all these findings about the meaning of some EEG markers in the assessment of brain functions in the childhood we would like to promote the brain rate - $\mathrm{fb}$ as an indicator of general mental activity which can allow us to put the analyzed groups in the group of underarousal disorders. Of course, further research is needed.

\section{REFERENCES}

1. Daniel Kahnemann Attention and Effort, Prentice-Hall, New Jersey. (1973).

2. Pop-Jordanova Nada, Pop-Jordanov Jordan. "Spectrum Weighted EEG Frequency ("Brain Rate") as a Quantitative Indicator of Mental Arousal", Prilozi, 26, 2 (2005): 35-42.

3. Johnstone Jack, Jay Gunkelman, J. Lunt. "Clinical database development: Characterization of EEG Phenotipes", Clin EEG Neurosci. 36, 2, (2005): 99-107.

4. World Health Organization: The ICD-10 classification of mental and behavioural disorders. Diagnostic criteria for research. World Health Organization (1993).

5. Clark Richard, Cherry Galletly, David Ash, et al. "Evidence-based medicine evaluation of electrophysiological studies of the anxiety disorders". Clin EEG Neurosci.; 40, 2, (2009): 84-112.

6. Ortony Andrew, Terence Turner. "What is Basic about Basic Emotions", Psychological Review; 97, 3, (1990): 315-331.

7. Tracy Jesica, Daniel Randles. "Four Models of Basic Emotions: A Review of Ekman and Cordaro", Izard, Levenson, and Panksepp and Watt, Emotion Review; 3, 4, (2011): 397-405.

8. Grunwald Martin, Christine Ettrich, Bianca Assmann, Angelica Dähne, et al. "Haptic perception and EEG changes in anorexia nervosa". Z Kinder Jugendpsychiatr Psychother; 27 (1999): 241-50.

9. Jáuregui-Lobera Ignacio. "Electroencephalography in eating disorders" Neuropsychiatr Dis Treat; 8 (2012):1-11.

10. Hatch Ainslie, Sloan Madden., Michael Kohn et al. "EEG in adolescent anorexia nervosa: impact of refeeding and weight gain". The International journal of eating disorders. 44, 1, (2011): 65-75.

11. Tchanturia Kate, Iain Campbell, Robin Morris \& Janet Treasure. "Neuropsychological studies in anorexia nervosa". The International journal of eating disorders; 37 (2005) Suppl, S72-6.

12. Rodriguez G, Babiloni C, Brugnolo A, Del Percio C, Cerro F, Gabrielli F et al. "Cortical sources of awake scalp EEG in eating disorders". Clin Neurophysiol;118 (2007): 1213-22.

13. Demerdzieva Aneta, Pop-Jordanova Nada. "Spectrum-weighted EEG frequency as an indicator of mental arousal in patients with anorexia". Medicina Fluminensis; 47, 3, (2011): 287-293.

14. Chabot John, di Michele F, Lesley Prichep, Roy John. "The Clinical Role of Computerized EEG in the Evaluation and Treatment of Learning and Attention Disorders in Children and Ado- 
lescents" J Neuropsychiatry Clin Neurosci; 13 (2001):171-186.

15. Kropotov Jury. Quantitative EEG, event-related potentials and neurotherapy, Elsevier Inc. (2008).

16. Johnstone Jeanette, Jay Gunkelman, Lunt J. "Clinical database development: characterization of EEG phenotypes". Clin EEG Neurosci.; 36, 2, (2005): 99-107.

17. Lubar Joel. "Discourse on the development of EEG diagnostics and biofeedback for attention-deficit/hyperactivity disorders". Biofeedback Self Regulation; 16 (1991): 201-225.

18. Demerdzieva Aneta. "EEG spectra power characteristics of attention deficit hyperactiv- ity disorder in childhood". Epilepsy (The Journal of the League against Epilepsy of Republic of Macedonia), (2010): 77-88.

19. Pop-Jordanov Jordan, Pop-Jordanova Nada. "Neurophysical substrates of arousal and attention", Cognitive Processin; 10(Suppl 1) (2009):S71-S79.

20. Cooper Nigel, Rodney Croft, Dominey SJ et al. "Paradox lost? Exploring the role of alpha oscillations during externally vs. internally directed attention and the implications for idling and inhibition hypotheses". International J Psychophysiol; 47, 1, (2003): 65-74.

\title{
Резиме
}

\section{ПАРАMЕTAPOT BRAIN-RATE КАЈ ДЕЦА СО ГЕНЕРАЛИЗИРАНО АНКСИОЗНО РАСТРОЈСТВО}

\author{
Анета Демерџиева ${ }^{1}$ и Нада Поп-Јорданова ${ }^{2}$ \\ ${ }^{1}$ Аџибадем Систина, Скопје, Република Македонија \\ ${ }^{2}$ Македонска академија на науките и уметностите, Скопје, Република Македонија
}

Вовед: Brain rate претставува параметер корелиран со метаболната и електричната активност на мозокот.

Цел: Целта на истражувањето е да се пресмета и да се спореди параметарот brain rate како индикатор за општата мозочна возбуденост кај анксиозни пациенти и резултатите да се споредат со оние кај здрави, како и кај деца со анорексија и дефицит на вниманието.

Материјал и метод: Дијагнозата кај сите испитаници е поставена врз основа на два статистички прирачници (DMS-IV и ICD-10), медицинската историја, невропсихолошката процена, биохемиските анализи и QEEG. Во оваа студија е испитувана спектралната моќност на мозочните бранови преку квантитативно ЕЕГ. Добиените резултати се експортирани во софтвер за brain rate и пресметувани за секој регион посебно. Податоците од QEEG и brain rate се анализирани со користење на статистички софтвер.

Резултати: Според сагиталната и латералната топографија, максимални вредности на параметарот brain rate се добиени кај групите здрави испитаници и кај оние со анорексија. Најниски резултати се добиени кај хиперактивните деца во сите три региони.

Заклучок: Општ заклучок е дека сите патолошки состојби во детството (особено анксиозните) анализирани во ова истражување може да се дефинираат како состојби на смалена ментална возбуденост, што може да биде специфичен знак за мозочна дисфункција.

Клучни зборови: QEEG, brain rate 